\title{
A Computer Program to Improve the Efficiency and Accuracy of Postulating Race-Specific Resistance Genes
}

\author{
Yeshi A. Wamishe, Department of Plant Pathology, University of Arkansas, Fayetteville 72701; Kevin C. Thomp- \\ son, Agricultural Statistics Laboratory, University of Arkansas, Fayetteville 72701; and Eugene A. Milus, Depart- \\ ment of Plant Pathology, University of Arkansas, Fayetteville 72701
}

\begin{abstract}
Wamishe, Y. A., Thompson, K. C., and Milus, E. A. 2004. A computer program to improve the efficiency and accuracy of postulating race-specific resistance genes. Plant Dis. 88:545-549.

Gene postulation has been the most widely used technique to determine the presence of particular rust resistance genes in lines of small grains. It applies the principles of gene-for-gene specificity to determine the most probable race-specific resistance genes present in host lines. As the numbers of lines, resistance genes, and races increase, postulation based on visual comparisons of infection types becomes more complex and laborious, and errors may occur. A computer program was developed to facilitate identification of race-specific leaf rust $(L r)$ genes in wheat (Triticum aestivum). Seedlings of 116 contemporary lines of soft red winter wheat and 24 Thatcher isolines (each Thatcher isoline with a single $L r$ gene) were inoculated with 22 races of Puccinia triticina. Infection types were recorded on the standard 0 to 4 scale where infection types 3 and 4 were considered high (line was susceptible; race was virulent) and others were low (line was resistant; race was avirulent). Based on the gene-for-gene concept, lines susceptible to a particular race cannot have an $L r$ gene for which the race is avirulent. For each line, step 1 of the program summarized results from races that were virulent on the line to definitively exclude $L r$ genes from the line, and this exclusion resulted in a relatively short list of $L r$ genes that could be present. Step 2 of the program utilized data from races that were avirulent on the line, and the output listed the low infection types produced on the line and the isolines with $\mathrm{Lr}$ genes that were not excluded in step 1 . Of these $L r$ genes, a gene was considered present if the low infection type produced on the line by one or more races matched the low infection type on the corresponding isoline. Otherwise, the gene was considered possibly present. Epistatic effects of one or more $L r$ genes prevented definitive inclusion or exclusion of genes considered possibly present. If the low infection type produced on the line was lower than that on any of the isolines listed in step 2, then the line was considered to have an unidentified $L r$ gene; i.e., a gene that was not in the set of 24 isolines. This program facilitated the objective and accurate postulation of $L r$ genes and could be adapted to other host-pathogen systems.
\end{abstract}

Race-specific resistance genes that are expressed in the seedling stage have been used to protect wheat (Triticum aestivum L.) from leaf rust caused by Puccinia triticina Eriks. (syn: Puccinia recondita Rob. ex. Desm. f. sp. tritici). At least 45 leaf rust resistance $(L r)$ genes have been described in wheat (5). Because new races of $P$. triticina usually develop to attack cultivars with only one or a few of these genes, breeders attempt to pyramid several resistance genes in a cultivar to enhance durability of resistance $(8,9)$. Usually the

Corresponding author: Eugene A. Milus E-mail: gmilus@uark.edu

Current address of Y. A. Wamishe: Dale Bumpers National Rice Research Center, 2890 Hwy. 130 East P.O. Box 1090. Stuttgart, AR 72160.

Accepted for publication 5 January 2004.

Publication no. D-2004-0311-01S

(C) 2004 The American Phytopathological Society genes conferring leaf rust resistance are not known in parents used by breeders or in cultivars that are released. Knowing which genes are responsible for leaf rust resistance would facilitate development and deployment of resistant cultivars to manage leaf rust (7).

Gene postulation applies the principles of gene-for-gene specificity to determine the most probable race-specific resistance genes present in a host line (2). Flor (1) was the first to use gene postulation, and the technique has been widely used to identify genes for rust resistance in small grains $(6,7,10,11)$. Genetic interactions between wheat and $P$. triticina operate in a gene-for-gene relationship (7). Therefore, the presence of race-specific resistance genes can be postulated based on infection types expressed when wheat lines are inoculated with a series of pathogen races of known virulence (5). Infection type is the phenotype resulting from the interaction between a race of the pathogen and a genotype of the host under certain environ- mental conditions $(7,12)$. For identifying resistance genes, Loegering and Burton (3) determined that gene postulation was as useful as genetic studies involving segregating populations.

The presence of $L r$ genes in wheat lines has been postulated manually by comparing infection types produced on lines with infection types produced on isolines that have a single $\operatorname{Lr}$ gene $(7,10)$. Comparison of infection types becomes complex as the numbers of lines, resistance genes, and races increase. As complexity increases, visual comparisons become laborious, and errors may occur. However, computers are useful for analyzing complex data quickly and accurately.

A computer program that utilized Boolean algebra was used by Loegering et al. (4) to compare and group patterns of low and high infection types. Loegering and Burton (3) developed a computer program that used internal and external correlation and a "boxing" program to generate hypothetical genotypes for high/low reactions. Although other researchers have not used these programs, these publications advanced the theory and validity of postulating resistance genes. No other computer programs for postulating resistance genes have been published. The objective of this study was to develop a computer program that utilized commonly available software to facilitate postulation of leaf rust resistance genes in wheat and that could be adapted to other host-pathogen systems.

\section{MATERIALS AND METHODS}

Infection type data for 116 contemporary lines of soft red winter wheat and 24 isolines in a Thatcher background that were inoculated with 22 races of $P$. triticina in a previous study (13) were used to develop the computer program. Infection types were recorded using the 0 to 4 scale (12) in which infection types 3 and 4 were considered high (line was susceptible; race was virulent) and others were low (line was resistant; race was avirulent). Each race by wheat line combination was tested at least twice, and each repetition was analyzed separately rather than being averaged.

Infection type data for isolines and lines were organized in separate data sets that 
had identical column names and data types. At least one column (called "line") uniquely identified the isoline/line, and the remaining columns contained infection types for each repetition of each race by isoline and race by line combination used in the study.

SAS (Statistical Analysis Systems, Cary, NC) software was chosen because of its versatility and widespread availability, and the program was written as an SAS Macro. In addition to the line and isoline data sets described previously, the program required

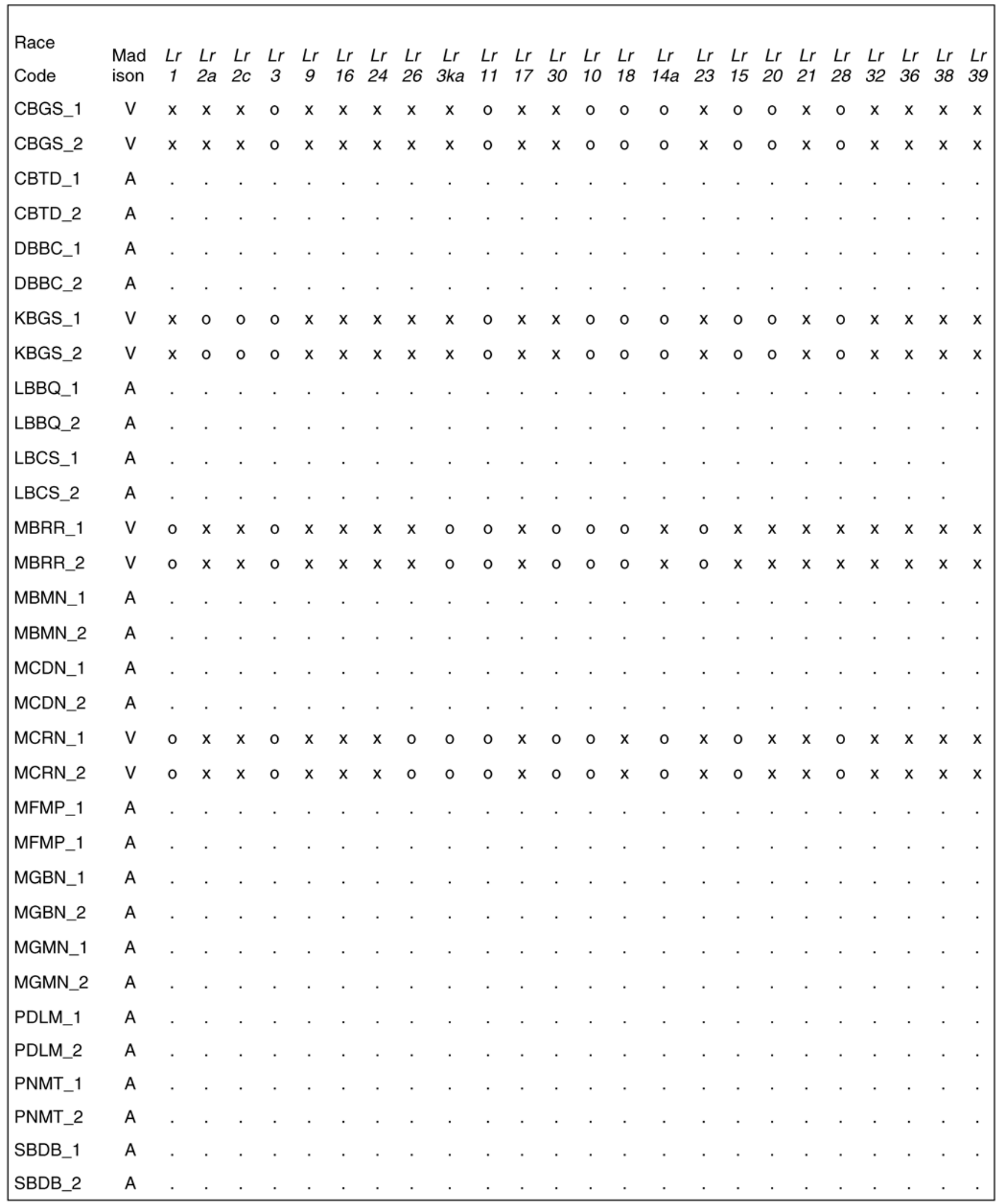

(continued on next page)

Fig. 1. Output from step 1 of the computer program for cultivar Madison identifying $L r$ genes that may be present and genes that cannot be present. . $=$ race was avirulent on Madison, and no useful information was obtained for this step of the program. o = race was virulent on Madison and on the $L r$ gene, indicating this gene could be in Madison unless eliminated by results from another race. $\mathrm{x}=$ race was virulent on Madison but avirulent on the gene, indicating this gene could not be in Madison, and this information was summarized across all races to exclude genes from Madison. $V=$ virulent on wheat cultivar Madison, A = avirulent on Madison. Each race by Madison combination was tested twice. 
infection types to be classified as either high (virulent) or low (avirulent). If an infection type was not classified as high or low, the program prompted the user to classify it. The GenePostulation Macro program included comments and error messages to assist users. The complete computer program is available at http://www.uark.edu/depts/plntpath/MILUS. dir/Milus.html or by contacting the corresponding author.

To exclude $L r$ genes from a line and obtain a relatively short list of $L r$ genes that could be present in a line, step 1 of the program utilized data from races virulent on a line as determined from infection type data in the line data set. Lines susceptible to a given race cannot have any of the $L r$ genes for which the race is avirulent as determined from the isoline data set. Step 2 of the program considered only $L r$ genes not excluded in step 1 and utilized data from races that were avirulent on the line. To facilitate postulating the presence of $L r$ genes in a line by matching infection types, output from step 2 listed the low infection types produced on the line and the isolines of $L r$ genes being considered.

To postulate $L r$ genes by matching infection types, the low infection types listed in the output of step 2 were compared visually. Of the $L r$ genes listed in step 2, a gene was considered present if the low infection type produced on the line by one or more races matched the low infection type on the corresponding isoline. Otherwise, the gene was considered possibly present. Because the lowest infection type was epistatic over other low infection types, it was not possible to definitively include or exclude genes considered possibly present with the races used in the study. If the infection type on a line was lower than that on any of the isolines listed in step 2, then the line was considered to have an unidentified gene that was not included in the set of 24 isolines.

To evaluate the efficiency of the method used in this study, relationships of the number of races virulent on a line with the number of $L r$ genes excluded in step 1 and the number of genes possibly present in a line were examined. The GenePostulation macro produced a data set that included the number of virulent races on each line and the number of genes excluded from each line. The number of genes possibly present in each line was determined after infection types in step 2 were compared visually as described above and added manually to the data set. An SAS program was used to plot relationships between the number of races virulent on a line against the number of $L r$ genes excluded from a line in step 1 and the number of genes possibly present.

\section{RESULTS AND DISCUSSION}

The SAS Macro computer program analyzed infection type data for each line and produced output in two steps. Step 1 identified $L r$ genes that cannot be present and $L r$ genes that may be present in the lines. Figure 1 shows an example of the output from step 1 of the program for cultivar Madison. Races CBGS, KBGS, MBRR, MCRN, TCRN, TDRP, TFRP, TLGM, and TLRT were virulent on Madison but aviru- lent on $L r$ genes that were indicated with " $x$ ". This information was summarized across all races and indicated that genes Lrl, 2a, 2c, 9, 16, 24, 26, 3ka, 17, 30, 18, $14 a, 23,15,20,21,28,32,36,38$, and 39 cannot be in Madison. Genes Lr3, 10, and 11 were not excluded by step 1 of the program and may be present in Madison.

The output of step 2 for Madison (Fig. 2) listed races that were avirulent on Madison, the low infection types that were produced on Madison, and the isolines having $L r$ genes that were not excluded in step 1 . The low infection type on Madison produced by races CBTD and LBCS matched the infection type on isolines with $\mathrm{Lr} 10$ and 3 , respectively, and indicated the presence of $\operatorname{Lr} 3$ and 10 in Madison. Results with races DBBC and SBDB supported the presence of $\operatorname{Lr} 3$ and 10 but did not show them separately. The infection types on Madison produced by races MBMN, MCDN, PNMT, PDLM, and TBPM matched the infection types produced on the isoline for Lr11, indicating the presence of $L r 11$.

Data from the two repetitions showed that races MFMP, MGBN, and MGMN produced lower infection types on Madison than on any of the isolines, indicating the presence of at least one additional unidentified $\mathrm{Lr}$ gene. Following accepted procedures (7), the symbol "+" was used to indicate the unidentified gene. Lines with lower infection types than any of the isolines listed in step 2 of the output were objectively postulated to have one or more resistance genes that were not included in the isoline data set. Therefore, the genes

\begin{tabular}{|c|c|c|c|c|c|c|c|c|c|c|c|c|c|c|c|c|c|c|c|c|c|c|c|c|c|}
\hline $\begin{array}{l}\text { Race } \\
\text { Code }\end{array}$ & $\begin{array}{l}\text { Mad } \\
\text { ison }\end{array}$ & $\begin{array}{c}L r \\
1\end{array}$ & $\begin{array}{l}L r \\
2 a\end{array}$ & $\begin{array}{l}L r \\
2 c\end{array}$ & $\begin{array}{c}L r \\
3\end{array}$ & $\begin{array}{c}L r \\
9\end{array}$ & $\begin{array}{l}L r \\
16\end{array}$ & $\begin{array}{l}L r \\
24\end{array}$ & $\begin{array}{l}L r \\
26\end{array}$ & $\begin{array}{c}L r \\
3 k a\end{array}$ & $\begin{array}{l}L r \\
11\end{array}$ & $\begin{array}{l}L r \\
17\end{array}$ & $\begin{array}{l}L r \\
30\end{array}$ & $\begin{array}{l}\mathrm{Lr} \\
10\end{array}$ & $\begin{array}{l}L r \\
18\end{array}$ & $\begin{array}{c}L r \\
14 a\end{array}$ & $\begin{array}{l}L r \\
23\end{array}$ & $\begin{array}{l}L r \\
15\end{array}$ & $\begin{array}{l}L r \\
20\end{array}$ & $\begin{array}{l}L r \\
21\end{array}$ & $\begin{array}{l}L r \\
28\end{array}$ & $\begin{array}{l}L r \\
32\end{array}$ & $\begin{array}{l}L r \\
36\end{array}$ & $\begin{array}{l}L r \\
38\end{array}$ & $\begin{array}{l}L r \\
39\end{array}$ \\
\hline TBPM_1 & A & . & . & . & . & . & . & . & . & . & . & . & . & . & . & . & . & . & . & . & . & . & . & . & . \\
\hline TBPM_2 & A & . & . & . & . & . & . & . & . & . & . & . & . & . & . & . & . & . & . & . & . & . & . & . & . \\
\hline TCRN_1 & V & 0 & 0 & 0 & 0 & $x$ & $x$ & $x$ & 0 & 0 & 0 & $x$ & 0 & 0 & $x$ & 0 & 0 & $x$ & $x$ & $x$ & 0 & $x$ & $x$ & $x$ & $x$ \\
\hline TCRN_2 & V & 0 & 0 & 0 & 0 & $x$ & $x$ & $x$ & 0 & o & 0 & $x$ & 0 & 0 & $x$ & 0 & 0 & $x$ & $x$ & $x$ & 0 & $x$ & $x$ & $x$ & $x$ \\
\hline TDRP_1 & V & 0 & 0 & 0 & 0 & $x$ & $x$ & 0 & $x$ & o & 0 & $x$ & 0 & 0 & $x$ & 0 & 0 & 0 & 0 & $x$ & 0 & $x$ & $x$ & $x$ & $x$ \\
\hline TDRP_2 & V & 0 & 0 & 0 & 0 & $x$ & $x$ & 0 & $x$ & 0 & 0 & $x$ & 0 & 0 & $x$ & 0 & 0 & 0 & 0 & $x$ & 0 & $x$ & $x$ & $x$ & $x$ \\
\hline TFRP_1 & V & 0 & 0 & 0 & 0 & $x$ & $x$ & 0 & 0 & 0 & 0 & $x$ & 0 & 0 & $x$ & 0 & 0 & 0 & 0 & $x$ & 0 & $x$ & $x$ & $x$ & $x$ \\
\hline TFRP_2 & V & 0 & 0 & 0 & 0 & $x$ & $x$ & 0 & 0 & o & 0 & $x$ & 0 & 0 & $x$ & 0 & 0 & 0 & 0 & $x$ & 0 & $x$ & $x$ & $x$ & $x$ \\
\hline TLGM_1 & V & 0 & 0 & 0 & 0 & 0 & $x$ & $x$ & $x$ & $x$ & 0 & $x$ & $x$ & 0 & $x$ & $x$ & 0 & 0 & $x$ & $x$ & $x$ & $x$ & $x$ & $x$ & $x$ \\
\hline TLGM_2 & V & 0 & 0 & 0 & 0 & 0 & $x$ & $x$ & $x$ & $x$ & 0 & $x$ & $x$ & 0 & $x$ & $x$ & 0 & 0 & $x$ & $x$ & $x$ & $x$ & $x$ & $x$ & $x$ \\
\hline TLRT_1 & V & 0 & 0 & 0 & 0 & 0 & $x$ & $x$ & $x$ & o & 0 & $x$ & 0 & 0 & 0 & 0 & 0 & 0 & 0 & $x$ & 0 & $x$ & $x$ & $x$ & $x$ \\
\hline TLRT_2 & V & 0 & 0 & 0 & 0 & 0 & $x$ & $x$ & $x$ & 0 & 0 & $x$ & 0 & 0 & 0 & 0 & 0 & 0 & 0 & $x$ & 0 & $x$ & $x$ & $x$ & $x$ \\
\hline & & - & - & - & - & - & - & - & - & - & - & - & - & - & - & - & - & - & - & - & - & - & - & - & - \\
\hline Summary & & $x$ & $x$ & $x$ & 0 & $x$ & $x$ & $x$ & $x$ & $x$ & 0 & $x$ & $x$ & 0 & $x$ & $x$ & $x$ & $x$ & $x$ & $x$ & $x$ & $x$ & $x$ & $x$ & $x$ \\
\hline
\end{tabular}

Fig. 1. (continued from previous page) 
controlling race-specific seedling resistance in Madison were $L r 3,10,11,+$.

Based on the 22 races, 116 lines, and 24 isolines used in this study, having one race virulent on a line excluded at least nine $L r$ genes from a line (Fig. 3). The number of excluded genes increased rapidly as the number of races virulent on a line increased to seven, after which the number of excluded genes increased slowly. Likewise, the number of $\mathrm{Lr}$ genes listed as possibly present in a line decreased rapidly as the number of races virulent on a line increased from zero to seven (Fig. 3). If seven or more races were virulent on a line, then the number of genes possibly present was almost always reduced to zero, indicating that nearly all of the genes in the

\begin{tabular}{|cccccc|}
\hline Race & Madi & & & \\
Code & son & Lr3 & Lr11 & Lr10 \\
CBTD 1 & $:$ & & & $:$ \\
CBTD 2 & $:$ & & & $:$ \\
DBBC 1 & 1 & $:$ & $2:$ & 1 \\
DBBC 2 & $:$ & $:$ & $2:$ & 1 \\
LBBQ 1 & 2 & 12 & 1 & \\
LBBQ 2 & 2 & 2 & 1 & \\
LBCS 1 & $: 1$ & $:$ & $22+$ & $22+$ \\
LBCS 2 & $:$ & $: 1$ & 2 & $2+$ \\
MBMN 1 & $2+$ & & $2+$ & \\
MBMN 2 & $2+$ & & $2+$ & \\
MCDN 1 & 2 & & $2+$ & \\
MCDN 2 & $2+$ & & $2+$ & \\
MFMP 1 & $:$ & & $2+$ & \\
MFMP 2 & $: 12$ & & $2+$ & \\
MGBN 1 & $:$ & & 2 & \\
MGBN 2 & $: 12$ & & 2 & \\
MGMN 1 & $: 2+$ & & 2 & \\
MGMN 2 & $: 2+$ & & 1 & \\
PDLM 1 & $: 1$ & & $: 1$ & \\
PDLM 2 & $:$ & & $: 1$ & \\
PNMT 1 & $2+$ & & $2+$ & \\
PNMT 2 & 2 & & $2+$ & \\
SBDB 1 & $:$ & $:$ & $2+$ & $:$ \\
SBDB 2 & $:$ & $:$ & $2+$ & $:$ \\
TBPM 1 & $:$ & & $:$ & \\
TBPM 2 & $;$ & & $;$ & \\
\hline
\end{tabular}

Fig. 2. Output from step 2 of the computer program for the cultivar Madison listing races of Puccinia triticina that were avirulent on Madison, their infection types on Madison, and the Thatcher isolines with $L r$ genes that were not eliminated by step 1 of the program. ; = hypersensitive necrotic or chlorotic flecks, $1=$ small uredia surrounded by necrosis, $2=$ medium uredia surrounded by necrosis or chlorosis, $+=$ uredia somewhat larger than normal for the infection type, and $-=$ uredia somewhat smaller than normal for the infection type. High infection types ( 3 or 4 ) are shown as blanks. More than one value indicates a range of infection type, and the predominant infection type was listed first. Each race by Madison combination was tested twice. isoline data set were postulated definitively as either present or absent in nearly all of the lines. Although the optimal number of races virulent on a line in other postulation studies would depend on the number of resistance genes being considered, the particular virulence combinations of races used, and the particular combinations of resistance genes in the lines, plotting the curves illustrated in Figure 3 provides a means for determining the completeness of postulation. This is the first report of the relationship between the number of races virulent on a line and the completeness of gene postulation.

The SAS macro computer program required the same data that have been used by other researchers to postulate resistance genes manually. Previous studies $(7,10,11)$ simply postulated which genes were found to be present with the races used in the study, and this was often an incomplete postulation. The program allowed each gene in the isoline data set to be classified as present, not present, or possibly present for each line and enhanced the objectivity, efficiency, accuracy, and confidence associated with postulating $L r$ genes. Objectivity was enhanced by definitively excluding genes that could not be in a line. Efficiency was enhanced by printing, in side-by-side format, only the infection types that needed to be compared manually. Accuracy was enhanced by using data from each of two repetitions of inoculations to independently postulate genes, and any discrepancy between the two repetitions was resolved by repeating particular race- by-line and race by isoline inoculations two additional times. Confidence was enhanced whenever more than one race supported the exclusion or inclusion of a particular gene. Furthermore, the program identified which combinations of virulence would be required to postulate the possibly present genes as either present or absent and make a complete postulation for all genes in the isoline data set. The program would be especially useful for postulating a large number of resistance genes in a large number of lines with a large number of races. The program can be adapted to other host-pathogen systems and other scales for infection type and is currently being used to postulate genes for stripe rust resistance using a 0 to 9 scale for infection type (E. A. Milus and Y. A. Wamishe, unpublished data).

\section{ACKNOWLEDGMENTS}

We thank David Long and Jim Kolmer from the USDA-ARS, Cereal Disease Laboratory, for providing pathogen isolates, seeds of isolines, advice, and information; Brent McCallum from the Cereal Research Centre Agriculture and Agri-Food, Canada, for providing pathogen isolates; and Ravi Singh from CIMMYT for useful comments and suggestions. Technical support from the wheat pathology team at the University of Arkansas and financial support from the Arkansas Wheat Promotion Board are gratefully appreciated.

\section{LITERATURE CITED}

1. Flor, H. H. 1955. Host-parasite interaction in flax rust-Its genetics and other implications. Phytopathology 45:680-685.

2. Kolmer, J. A. 1996. Genetics of resistance to wheat leaf rust. Annu. Rev. Phytopathol 34:435-455.

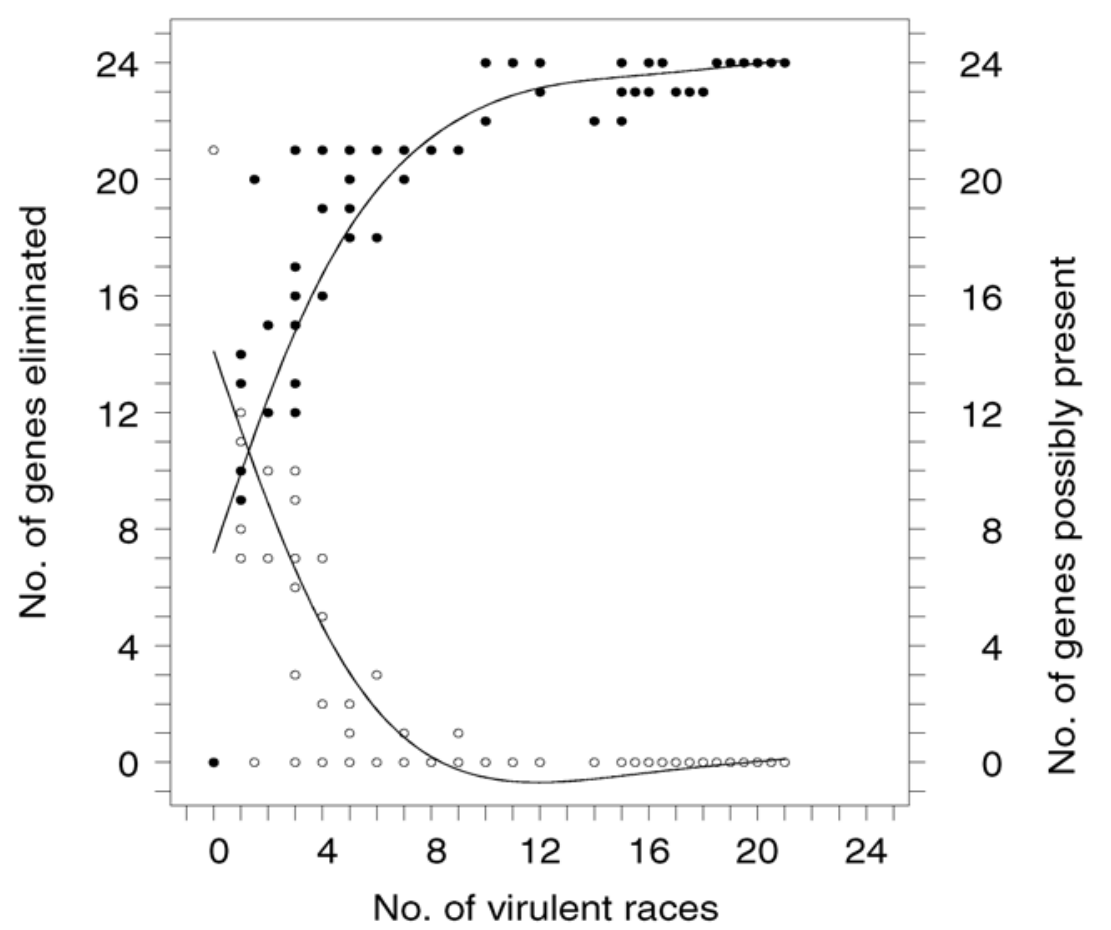

Fig. 3. Relationships, based on the 116 wheat lines, $24 \mathrm{Lr}$ genes, and 22 races of Puccinia triticina used in this study, between the number of races virulent on a line and the number of $L r$ genes eliminated from a line in step 1 of the computer program $(\bullet)$, and the number of $L r$ genes listed as possibly present in a line (o). Some points represent more than one data point. 
3. Loegering, W. Q., and Burton, C. H. 1974. Computer-generated hypothetical genotypes for reaction and pathogenicity of wheat cultivars and cultures of Puccinia graminis tritici. Phytopathology 64:1380-1384.

4. Loegering, W. Q., McIntosh, R. A., and Burton, C. H. 1971. Computer analysis of disease data to derive hypothetical genotypes for reaction of host varieties to pathogens. Can. J. Genet. Cytol. 13:742-748.

5. McIntosh, R. A., Wellings, C. R., and Park, R. F. 1995. Wheat Rusts: An Atlas of Resistance Genes. Kluwer Academic Publishers, London.

6. McVey, D. V. 1992. Genes for rust resistance in international winter wheat nurseries XII through XVII. Crop Sci. 32:891-895.

7. McVey, D. V., and Long, D. L. 1993. Genes for leaf rust resistance in hard red winter wheat cultivars and parental lines. Crop Sci. 33:13731381.

8. Roelfs, A. P. 1988. Resistance to leaf and stem rust in wheat. Pages 10-22 in: Breeding Strategies for Resistance to the Rusts of Wheat. N. W. Simmonds and S. Rajaram, eds. CIMMYT, Mexico D.F.

9. Samborski, D. J., and Dyck, P. L. 1976. Inheritance of virulence in Puccinia recondita on six backcross lines of wheat with single genes for resistance to leaf rust. Can. J. Bot. 54:16661671.
10. Singh, D., Park, R. F., and McIntosh, R. A 2001. Postulation of leaf (brown) rust resistance genes in 70 wheat cultivars grown in the United Kingdom. Euphytica 120:205-218.

11. Singh, R. P. 1993. Resistance to leaf rust in 26 Mexican wheat cultivars. Crop Sci. 33:633 637.

12. Stakman, E. C., Stewart, D. M., and Loegering, W. Q. 1962. Identification of physiological races of Puccinia graminis var. tritici. U.S Dep. Agric. Agric. Res. Serv. Bull. E617 (Revised 1962).

13. Wamishe, Y. A., and Milus, E. A. 2004. Seedling resistance genes to leaf rust in soft red winter wheat. Plant Dis. 88:136-146. 